\title{
Quantitative and qualitative characteristics of the non-carcass components and the meat of lambs fed sunflower seeds and vitamin $E$
}

\author{
Natália Ludmila Lins Lima ${ }^{1}$, Américo Garcia da Silva Sobrinho ${ }^{1}$, Fabiana Alves de Almeida ${ }^{1}$, \\ Viviane Endo ${ }^{1}$, Nivea Maria Brancacci Lopes Zeola ${ }^{1}$, Amélia Katiane de Almeidaa ${ }^{1}$, Alexandre \\ Amstalden Moraes Sampaio ${ }^{1}$
}

\footnotetext{
${ }^{1}$ Departamento de Zootecnia, FCAV - Unesp, Jaboticabal, SP, Brazil.
}

\begin{abstract}
The objective of this investigation was to evaluate the weight and percentage of the non-carcass components and the mineral content (macro minerals and trace minerals), crude protein, ether extract, moisture and vitamin E of the heart, liver, tongue, lungs, reticulum, kidneys and meat from the longissimus dorsi of lambs in feedlot finishing. Thirty-two noncastrated Ile de France male lambs, fed diets containing sunflower seeds and vitamin E from 15 to $32 \mathrm{~kg}$ of body weight were allotted in a completely randomized design in a $2 \times 2$ factorial arrangement. The weight of the gastrointestinal tract was higher in the lambs fed diets containing vitamin E (10\%). No difference was observed in the liver as to the mineral matter, crude protein, ether extract, moisture $(2.01 ; 20.03 ; 2.39$ and $74.78 \mathrm{~g} / 100 \mathrm{~g}$, respectively), the macro minerals and trace minerals, except iron. In the tongue, lungs, reticulum, kidneys and meat there was no in fluence of diets in the studied variables. The liver and the meat presented different values of crude protein (20.01 and $18.34 \mathrm{~g} / 100 \mathrm{~g}$, respectively), and the heart (1.03 $\mathrm{mg} / 100 \mathrm{~g})$ showed a higher content of vitamin E. High contents of manganese, zinc and copper were observed in the liver. The evaluated non-carcass components were nutritionally equal to the sheep meat, once, in addition to their high yield in relation to the body weight at slaughter, the non-carcass components are sources of nutrients.
\end{abstract}

Key Words: minerals, organs, viscera, vitamin E, yield

\section{Introduction}

The importance of studies about the non-carcass components is associated not only with the possibility of increasing the economic return at the moment of the commercialization of sheep products, but also with the feed and raw materials which are lost and that could collaborate with the improvement of the nutritional level of populations (Yamamoto et al., 2004).

There is a lower valorization of the non-carcass components of small ruminants when compared with another animal species used for human food, and their consumption must be stimulated, due to the large number of culinary dishes using them, besides being an extra source of income (Cezar \& Sousa, 2007). In the Northeast region of Brazil, the commercial value of organs and viscera represents around $16.4 \%$ of the sale price of the live animal and $15.9 \%$ of the carcass price (Costa et al., 2007).

The manipulation of the diets, in addition to improving the quality of sheep products, increases profitability in the production of lambs, but an increase in the use of the animal as a whole is also necessary to make the activity profitable. Studies that show the influence of the diet in the nutritional composition of the non-carcass components have not been published; they are important to the appreciation and are a stimulus to the consumption of this part of the animal, which is usually neglected.

In order to make the production of lambs in feedlot a more profitable activity, it is indispensable to use more economical food of easy availability. The sugar cane is an alternative of forage of high productivity and easy growth, and it can be associated with the inclusion of sunflower seeds, increasing the polyunsaturated fatty acids in the meat of the animals. Moreover, when this fat is consumed by humans it plays an important role in the prevention of cardiovascular diseases (Shapiro et al., 1996). The inclusion of vitamin E in the diets of ruminants as a natural antioxidant favors the oxidative stability of the edible products, and its ingestion by humans prevents diseases (Brigelius et al., 2002), being characterized as a nutraceutical food. According to Hathcock (1997), the daily ingestion of at least $67 \mathrm{mg}$ of vitamin $\mathrm{E}$ is related to a decrease in the risks of cardiovascular diseases, and the non-carcass components are alternative sources of vitamin E.

The objective of this investigation was to evaluate quantitatively the non-carcass components and qualitatively the heart, liver, tongue, lungs, reticulum, kidneys and meat from the longissimus dorsi muscle of lambs fed sunflower 
seeds and vitamin $\mathrm{E}$ in the concentrate, in addition to making a comparison between the non-carcass components and their meat.

\section{Material and Methods}

The trial was carried out in the Faculdade de Ciências Agrárias e Veterinárias, FCAV/UNESP, Jaboticabal - SP, Brazil. The field phase and the slaughter of the animals were conducted in the facilities of Setor de Ovinocultura and the chemical and bromatological analysis of the diets and the centesimal composition of the meat and of the non-carcass components were done in the Laboratório de Nutrição Animal (LANA) of Departamento de Zootecnia, except the analysis of the vitamin $\mathrm{E}$, which was done in the Instituto de Tecnologia de Alimentos, Campinas - SP, Brazil.

Thirty-two non-castrated Ile de France male lambs weaned at body weight of $15 \mathrm{~kg}$ were allotted in suspended individual pens with slatted floor of approximately $1.0 \mathrm{~m}^{2}$, equipped with individual feeders and drinkers, installed in a covered shed.

Before the beginning of the trial, the worm monitoring of the animals was done through the Famacha ${ }^{\circledR}$ method, following the recommendations of Molento et al. (2004), and through the number of eggs of nemathods per gram of faeces (EPG), using the modified McMaster method described by Sloss et al. (1999). The deworming was done when the count was higher than 1000 EPG.

The treatments consisted of the following diets: sugarcane + concentrate without sunflower seeds; sugarcane + concentrate with sunflower seeds; sugarcane + concentrate without sunflower seeds $+1000 \mathrm{mg}$ vit. E $/ \mathrm{kg}$ of dry matter (DM) of the diet; and sugarcane + concentrate with sunflower seeds $+1000 \mathrm{mg}$ vit. E $/ \mathrm{kg}$ of DM of the diet (Tables 1 and 2).

The diets were formulated in accordance with the requirements established by the NRC (2006) for weaned

Table 1 - Chemical and bromatological composition of the ingredients of the experimental diets $(\mathrm{g} / \mathrm{kg}$ of dry matter)

\begin{tabular}{lcccc}
\hline Nutrient & $\begin{array}{c}\text { Sunflower } \\
\text { seed }\end{array}$ & Sugar cane & $\begin{array}{c}\text { Soybean } \\
\text { meal }\end{array}$ & Ground corn \\
\hline Dry matter & 930.0 & 283.0 & 904.6 & 879.7 \\
Organic matter & 892.8 & 262.7 & 828.2 & 859.7 \\
Mineral matter & 37.2 & 20.3 & 76.4 & 20.0 \\
Crude protein & 142.5 & 27.8 & 466.3 & 85.6 \\
Ether extract & 280.6 & 05.9 & 20.8 & 49.6 \\
Neutral detergent fiber & 480.1 & 357.4 & 225.2 & 164.0 \\
Acid detergent fiber & 330.1 & 210.6 & 92.4 & 34.9 \\
Lignin & 22.1 & 34.7 & 22.0 & 24.4 \\
\hline
\end{tabular}

Analysis conducted at the Laboratório de Nutrição Animal (LANA) of FCAV, UNESP. lambs. Sugar cane of the forage variety IAC 86-2480, chopped in particles of $1.0 \mathrm{~cm}$ and provided in natura was used. A forage:concentrate ratio of 50:50 was offered ad libitum, from $08 \mathrm{~h} 00$ to $17 \mathrm{~h} 00$, and the weight of the feed supplied was recorded, calculated so as to allow $10 \%$ of leftovers.

The lambs were slaughtered with a body weight of $32.0 \pm 0.2 \mathrm{~kg}$ after a period of 16 hours of solid food deprivation. The animals were stunned by electronarcosis with an electric current of $220 \mathrm{~V}$ during 3 seconds, and the jugular vein and the carotid artery were sectioned, in accordance with humane slaughter procedures (Monteiro Júnior, 2000). Then, the contents of the gastrointestinal tract, gallbladder and bladder were removed and emptied to obtain the empty body weight (EBW = live weight at slaughter gastrointestinal content - gallbladder and bladder contents). The following non-carcass components were separated and weighted for the determination of their percentages in relation to the empty body weight: esophagus, tongue, blood, skin, reproductive system + bladder, spleen, liver, heart, respiratory tract + trachea, kidneys + perirenal fat, head, extremities of members (paws), pancreas, mesenteric and omental fats, gastrointestinal tract and content.

After 24 hours of storage in a cold chamber at $6^{\circ} \mathrm{C}$, the carcasses were cut lenghtwise, and the left half-carcasses were divided in five anatomic regions: neck, shoulder, ribs,

Table 2 - Composition of the experimental diets $(\mathrm{g} / \mathrm{kg}$ of dry matter)

\begin{tabular}{lcccc}
\hline \multirow{2}{*}{ Composition } & \multicolumn{4}{c}{ Treatment } \\
\cline { 2 - 5 } & $\mathrm{C}$ & $\mathrm{S}$ & $\mathrm{V}$ & $\mathrm{SV}$ \\
\hline Ground corn & 79.2 & 2.2 & 78.9 & 2.2 \\
Soybean meal & 380.5 & 377.5 & 380.5 & 376.6 \\
Sunflower seed & - & 80.9 & - & 80.8 \\
Sugar cane & 500.0 & 500.0 & 500.0 & 500.0 \\
Mineral premix ${ }^{1}$ & 4.9 & 4.9 & 4.9 & 4.9 \\
Iodized salt & 3.2 & 3.2 & 3.2 & 3.2 \\
Phosphate dicalcium & 8.1 & 8.1 & 8.1 & 8.1 \\
Urea & 13.2 & 11.5 & 13.3 & 11.5 \\
Limestone & 10.9 & 11.7 & 10.1 & 11.7 \\
Vitamin E & - & - & 1.0 & 1.0 \\
Chemical and bromatological composition & & & \\
Dry matter & 431.4 & 432.3 & 431.4 & 430.4 \\
Crude protein & 235.9 & 233.6 & 235.9 & 233.7 \\
Mineral matter & 65.9 & 67.8 & 65.6 & 68.2 \\
Ether extract & 14.8 & 33.6 & 14.8 & 33.6 \\
Neutral detergent fiber & 277.2 & 303.0 & 277.2 & 302.7 \\
Acid detergent fiber & 143.1 & 167.1 & 143.1 & 166.9 \\
Lignin & 27.6 & 27.5 & 27.6 & 27.5 \\
Gross energy (Mcal/kg DM) & 3.54 & 3.80 & 3.54 & 3.80 \\
\hline
\end{tabular}

$\mathrm{C}$ - control treatment; $\mathrm{S}$ - inclusion of sunflower seeds; $\mathrm{V}$ - inclusion of vitamin $\mathrm{E}$; $\mathrm{SV}$ - inclusion of sunflower seeds and vitamin E; DM - dry matter.

${ }^{1}$ Mineral premix: phosporus - $50 \mathrm{~g}$; calcium - $150 \mathrm{~g}$; sodium - $100 \mathrm{~g}$; magnesium - $5 \mathrm{~g}$; sulfur - $25 \mathrm{~g}$; zinc $-1500 \mathrm{mg}$; manganese - $500 \mathrm{mg}$; cobalt - $10 \mathrm{mg}$; iodine - $40 \mathrm{mg}$; selenium - $10 \mathrm{mg}$.

${ }^{2}$ Analysis conducted at the Laboratório de Nutrição Animal (LANA) of FCAV, UNESP. 
loin and leg, according to the methodology adapted from Garcia (1998) and Purchas et al. (2002).

The loin, along with the heart, liver, tongue, lungs, reticulum and kidneys were used for the centesimal analysis of the macro minerals, trace minerals and vitamin E, vacuum-packed and stocked in a freezer. The noncarcass components and the meat from the longissimus dorsi musclewere cut still frozen with a bandsaw, processed in a small grinder and homogenized, and samples of approximately $90 \mathrm{~g}$ were placed in Petri dishes for a later drying in a lyophilizer.

Moisture and mineral matter analysis were conducted in an oven and in a muffle, respectively, according to Silva \& Queiroz (2006), the determination of the crude protein was done by the semi-micro Kjedahl method according to Cunniff (1998) and the extraction of total lipids as the technique described by Silva \& Queiroz (2006). The vitamin $\mathrm{E}$ in the non-carcass components and in the meat of the lambs was determined according to the methodology of Brubacher et al. (1985). An acid digestion was performed for the analysis of minerals of the samples, according to Silva \& Queiroz (2006), and a dry mineral solution was obtained. The quantification of the calcium, potassium, magnesium, sodium, iron, copper, manganese and zinc was performed through atomic absorption spectrometry (Malavolta et al., 1989; Defelipo \& Ribeiro, 1981).

The design was completely randomized, in a $2 \times 2$ factorial arrangement (with or without the inclusion of sunflower seeds $\times 0$ or $1000 \mathrm{mg}$ of vitamin E/ $\mathrm{kg}$ DM of the diet), and means were compared using Tukey's test with a $5 \%$ significance level. Data were analyzed using the GLM procedure (General Linear Model) of SAS (Statistical Analysis System, version 9.2).

A completely randomized design with three treatments (control, vitamin E and sunflower + vitamin E) was used for the analysis of the vitamin E levels in the non-carcass components and in the meat, and the suppression of the treatment with inclusion of sunflower seeds only was necessary, due to the high costs of analyzing vitamin $\mathrm{E}$ in addition to problems during the trial. Means were compared using Tukey's test with a 5\% significance level, and data were analyzed using the GLM procedure (General Linear Model) of SAS (Statistical Analysis System, version 9.2).

In order to compare the nutritional value of the organs and viscera regardless of the diet provided and aiming at an appreciation of these items compared with the meat, a differentiated statistical analysis was conducted for the centesimal composition, macro minerals, trace minerals and vitamin $\mathrm{E}$, considering the non-carcass components and the meat as treatments for a comparison between them. A randomized block design was used, composed of the animals as the blocks, with seven treatments (heart, liver, tongue, lung, reticulum, kidneys and meat). Data, considered as repeated measures, were subjected to the Mixed procedure of SAS (Statistical Analysis System, version 9.2), and the analysis of variance was compared by Tukey's test with a $5 \%$ significance level.

\section{Results and Discussion}

There was no significant interaction between the inclusion of vitamin $\mathrm{E}$ and sunflower seeds in the diet $(P>0.05)$ on the weights and percentages of the non-carcass components. The weight of skin was lower $(\mathrm{P}<0.05)$ in the lambs fed vitamin E. Some differences in the weights of the non-carcass components were reported by Davoglio et al. (2007), who evaluated the weight and yield of the noncarcass components of $1 / 2$ Dorper $\times 1 / 2$ Santa Ines lambs and observed a higher weight of skin and head in the lambs fed diets without sunflower seeds ( 2.8 and $1.7 \mathrm{~kg}$, respectively), in comparison with those that received sunflower seeds ( 2.5 and $1.6 \mathrm{~kg}$, respectively). Homem Junior (2008) evaluated the inclusion of sunflower seeds or protected fat in the diet of Santa Ines lambs and found similar percentages for the non-carcass components, except for skin, which in the present study was higher, because the animals were from a wool breed.

According to Ferrell et al. (1976), the weights of liver and kidneys tend to increase with a higher ingestion of nutrients, especially energy and protein. However, the diets offered to the animals were isonitrogenous and isoenergetic, and there was no difference in the development of these organs. The inclusion of sunflower seeds in the diet of cattle, as in this study, did not influence the weights of the liver and of the kidneys + perirenal fat (Fernandes et al., 2008).

Sunflower seeds contain high contents of lipids, but they did not influence the visceral adipose deposits in this research, represented by omental and mesenteric fats (Table 3 ). Homem Junior (2008), however, reported an increase of the adipose deposits of lambs fed sunflower seeds as the lipid source when compared with the control diet, probably due to the energetic difference of the diets.

In the results reported by Homem Junior (2008), the inclusion of sunflower seeds in the diet did not influence the gastrointestinal tract content of lambs $(\mathrm{P}>0.05)$. However, it was higher in the diets with vitamin E (Table 3), which suggests that vitamin $E$ has some mechanism to reduce the passage rate of digesta and increases the content of the gastrointestinal tract, and more research is necessary to prove this fact. 
Regarding the influence of diets in the qualitative characteristics of the non-carcass components (nutritional composition), there was no influence of the diets or of their interaction in the centesimal composition of the heart, with mean values of $1.25 \mathrm{~g}$ of mineral matter/100 g, $14.85 \mathrm{~g}$ of crude protein/100 g, $9.57 \mathrm{~g}$ of ether extract/100 $\mathrm{g}$ and $73.48 \mathrm{~g}$ of moisture/100 g. Anderson (1988) studied the nutritional characteristics of the non-carcass components and raw and roast meats of different sheep categories and reported values of sodium, potassium, magnesium and calcium for the heart of $90 ; 316 ; 17$ and $6 \mathrm{mg} / 100 \mathrm{~g}$, respectively, similar to the results of this research, which were 87; 186; 15 and $6 \mathrm{mg} / 100 \mathrm{~g}$, respectively, considering the great variation of these trace minerals. For the trace minerals iron, manganese, zinc and copper in the heart, the same author found values of 4.65 ; $0.04 ; 1.89$ and $0.39 \mathrm{mg} / 100 \mathrm{~g}$, respectively, corroborating with the results of this research: 2.89; 0.04; 1.10 and $0.35 \mathrm{mg}$ / $100 \mathrm{~g}$, respectively, except for the iron content.

The centesimal composition and the contents of macro minerals and trace minerals in the liver were not influenced by the diet, except the iron content $(\mathrm{P}<0.05)$, presenting a higher value in the liver of lambs fed sunflower seeds and vitamin E (4.29 mg/100 g) (Table 4). The value found in this study was lower than the $7.47 \mathrm{mg}$ of iron/100 $\mathrm{g}$ of liver reported by Anderson (1988) in an evaluation of the minerals from the non-carcass components of sheep. For the macro minerals sodium, potassium and magnesium, the same author described the following values: $61 ; 245$ and $17 \mathrm{mg} /$ $100 \mathrm{~g}$, respectively, and for the trace minerals manganese, zinc and copper, values of $0.20 ; 4.46$ and $6.96 \mathrm{mg} / 100 \mathrm{~g}$, respectively, similar to the results of this research, 59; 234 and $18 \mathrm{mg} / 100 \mathrm{~g}$, respectively, for the macro minerals, and $0.27 ; 2.70$ and $4.61 \mathrm{mg} / 100 \mathrm{~g}$, respectively, for the trace minerals, except for zinc and copper, which were higher in the abovementioned research. Cole (1995) also reported values of calcium, potassium and manganese of 7, 260 and $17 \mathrm{mg} / 100 \mathrm{~g}$, respectively, in the sheep liver. Falandysz et al. (1991) evaluated iron, manganese, zinc and copper in the sheep liver and found values of $1.20 ; 0.07 ; 2.30$ and $4.10 \mathrm{mg} / 100 \mathrm{~g}$, respectively; the first two minerals were lower than the values observed in this study $(3.44 ; 0.27$; 2.70 and 4.61 , respectively).

Table 3 - Absolute weights $(\mathrm{kg})$ and percentage (\%) of non-carcass components of lambs fed diets containing sugar cane associated with sunflower seeds and vitamin E

\begin{tabular}{|c|c|c|c|c|c|c|c|c|c|}
\hline \multirow{2}{*}{ Variable } & & \multicolumn{2}{|c|}{ Sunflower seed (S) } & \multicolumn{2}{|c|}{ Vitamin E (E) } & \multicolumn{2}{|c|}{ Probability } & \multicolumn{2}{|c|}{ Interaction $(\mathrm{S} \times \mathrm{E}$} \\
\hline & & With & Without & With & Without & $\mathrm{S}$ & $\mathrm{E}$ & $\mathrm{CV}(\%)$ & $\mathrm{F}$ \\
\hline \multirow[t]{2}{*}{ Esophagus } & $\mathrm{kg}$ & 0.05 & 0.05 & 0.05 & 0.05 & 0.77 & 0.15 & 14.7 & 0.77 \\
\hline & $\%$ & 0.20 & 0.19 & $0.20 \mathrm{a}$ & $0.18 b$ & 0.45 & 0.04 & 13.6 & 0.93 \\
\hline \multirow[t]{2}{*}{ Tongue } & $\mathrm{kg}$ & 0.08 & 0.08 & 0.08 & 0.08 & 0.39 & 0.39 & 12.1 & 0.66 \\
\hline & $\%$ & 0.33 & 0.31 & 0.31 & 0.32 & 0.28 & 0.68 & 12.1 & 0.46 \\
\hline \multirow[t]{2}{*}{ Blood } & $\mathrm{kg}$ & 1.15 & 1.20 & 1.31 & 1.22 & 0.54 & 0.31 & 16.3 & 0.49 \\
\hline & $\%$ & 4.54 & 4.68 & 4.53 & 4.69 & 0.69 & 0.64 & 16.4 & 0.45 \\
\hline \multirow[t]{2}{*}{ Skin } & $\mathrm{kg}$ & 3.05 & 3.20 & $2.94 \mathrm{~b}$ & $3.31 \mathrm{a}$ & 0.29 & 0.02 & 10.3 & 0.66 \\
\hline & $\%$ & 12.00 & 12.46 & 11.76 & 12.70 & 0.35 & 0.07 & 8.8 & 0.72 \\
\hline \multirow[t]{2}{*}{ Reproductive system + bladder } & $\mathrm{kg}$ & 0.25 & 0.24 & 0.24 & 0.25 & 0.85 & 0.91 & 24.3 & 0.48 \\
\hline & $\%$ & 0.96 & 0.93 & 0.96 & 0.94 & 0.76 & 0.83 & 23.8 & 0.54 \\
\hline \multirow[t]{2}{*}{ Spleen } & $\mathrm{kg}$ & 0.05 & 0.05 & 0.05 & 0.06 & 0.84 & 0.34 & 21.5 & 0.84 \\
\hline & $\%$ & 0.20 & 0.20 & 0.19 & 0.21 & 0.95 & 0.38 & 21.3 & 0.87 \\
\hline \multirow[t]{2}{*}{ Liver } & $\mathrm{kg}$ & 0.51 & 0.51 & 0.50 & 0.52 & 1.00 & 0.37 & 9.6 & 0.33 \\
\hline & $\%$ & 2.00 & 1.99 & 2.00 & 1.99 & 0.81 & 0.89 & 8.6 & 0.15 \\
\hline \multirow[t]{2}{*}{ Heart } & $\mathrm{kg}$ & 0.14 & 0.14 & 0.14 & 0.14 & 0.44 & 0.87 & 10.1 & 0.44 \\
\hline & $\%$ & 0.54 & 0.55 & 0.56 & 0.54 & 0.60 & 0.44 & 9.9 & 0.84 \\
\hline \multirow[t]{2}{*}{ Respiratory tract + trachea } & $\mathrm{kg}$ & $0.75 b$ & $0.86 a$ & 0.78 & 0.83 & 0.02 & 0.28 & 12.1 & 0.24 \\
\hline & $\%$ & $2.96 \mathrm{~b}$ & $3.36 \mathrm{a}$ & 3.13 & 3.19 & 0.02 & 0.73 & 11.9 & 0.24 \\
\hline \multirow[t]{2}{*}{ Kidney + perirenal fat } & $\mathrm{kg}$ & 0.12 & 0.11 & 0.11 & 0.12 & 0.38 & 0.68 & 23.3 & 0.80 \\
\hline & $\%$ & 0.47 & 0.43 & 0.45 & 0.45 & 0.37 & 0.96 & 23.8 & 0.83 \\
\hline \multirow[t]{2}{*}{ Head } & $\mathrm{kg}$ & 1.68 & 1.69 & 1.65 & 1.71 & 0.98 & 0.17 & 5.7 & 0.13 \\
\hline & $\%$ & 6.60 & 6.54 & 6.58 & 6.56 & 0.67 & 0.84 & 4.4 & 0.11 \\
\hline \multirow[t]{2}{*}{ Foot } & $\mathrm{kg}$ & 0.81 & 0.83 & 0.81 & 0.83 & 0.41 & 0.41 & 5.2 & 0.16 \\
\hline & $\%$ & 3.21 & 3.24 & 3.26 & 3.19 & 0.73 & 0.42 & 6.0 & 0.12 \\
\hline \multirow[t]{2}{*}{ Pancreas } & $\mathrm{kg}$ & 0.04 & 0.05 & 0.05 & 0.04 & 0.11 & 0.11 & 17.1 & 0.58 \\
\hline & $\%$ & 0.18 & 0.17 & $0.18 \mathrm{a}$ & $0.16 b$ & 0.20 & 0.03 & 16.3 & 0.81 \\
\hline \multirow[t]{2}{*}{ Mesenteric and omental fat } & $\mathrm{kg}$ & 0.27 & 0.25 & 0.26 & 0.26 & 0.70 & 0.90 & 33.7 & 0.70 \\
\hline & $\%$ & 1.05 & 0.98 & 1.02 & 1.00 & 0.66 & 0.90 & 34.0 & 0.65 \\
\hline \multirow[t]{2}{*}{ Gastrointestinal tract } & $\mathrm{kg}$ & 2.44 & 2.30 & 2.49 & 2.26 & 0.29 & 0.09 & 12.0 & 0.69 \\
\hline & $\%$ & 9.67 & 9.03 & $10.00 \mathrm{a}$ & $8.70 \mathrm{~b}$ & 0.25 & 0.02 & 12.9 & 0.58 \\
\hline Content of the gastrointestinal tract & $\mathrm{kg}$ & 4.92 & 4.57 & $5.22 \mathrm{a}$ & $4.27 b$ & 0.27 & $<0.01$ & 14.9 & 0.52 \\
\hline
\end{tabular}

Means within a row followed by different letters differ $(\mathrm{P}<0.05)$ by the Tukey test. $\mathrm{CV}$ - coefficient of variation. 
No differences were observed $(\mathrm{P}>0.05)$ in the chemical composition and in the composition of macro minerals and trace minerals for the tongue, and the average values were $1.1 \mathrm{~g} / 100 \mathrm{~g}$ for mineral matter, $15.2 \mathrm{~g} / 100 \mathrm{~g}$ for crude protein, $5.6 \mathrm{~g} / 100 \mathrm{~g}$ for ether extract and $77.5 \mathrm{~g} / 100 \mathrm{~g}$ for moisture.

Anderson (1988) reported for the tongue a higher value of ether extract $(17.51 \mathrm{~g} / 100 \mathrm{~g})$ and a lower value of moisture $(66.72 \mathrm{~g} / 100 \mathrm{~g})$ when compared with the data described in this study. This can probably be explained by the use of adult lambs which presented more fat than young animals. Apparently, there is a negative correlation between the fat and the moisture for the tongue, as observed in the skeletal muscle tissue.

The centesimal composition of the lungs from the lambs fed diets containing sunflower seeds and vitamin E showed mean values of $0.9 \mathrm{~g}$ of mineral matter/100 $\mathrm{g}$, 15.2 of crude protein $/ 100 \mathrm{~g}, 1.1 \mathrm{~g}$ of ether extract $/ 100 \mathrm{~g}$ and $81.8 \mathrm{~g}$ of moisture $/ 100 \mathrm{~g}$, and there was no influence of the experimental diets on any variable $(\mathrm{P}>0.05)$. Anderson (1988) described for the sheep lungs, values of $16.7 \mathrm{~g}$ of crude protein/100 g, $2.6 \mathrm{~g}$ of ether extract/100 g and $79.7 \mathrm{~g}$ of moisture $/ 100 \mathrm{~g}$. The iron in this trial was higher $(8.3 \mathrm{mg} / 100 \mathrm{~g})$ than the value cited by the same author $(6.4 \mathrm{mg} / 100 \mathrm{~g})$.

There were no differences $(\mathrm{P}>0.05)$ in the chemical, macro mineral and trace mineral compositions in the reticulum of lambs fed sunflower seeds and vitamin E, and average values of $0.58 \mathrm{~g}$ of dry matter/100 g, $10.8 \mathrm{~g}$ of crude protein/100 g, $3.63 \mathrm{~g}$ of ether extract/100 $\mathrm{g}$ and $84.59 \mathrm{~g}$ of moisture/100 $\mathrm{g}$ were observed for the reticulum.

The lambs supplemented with vitamin $\mathrm{E}$ presented a higher content of iron in the kidneys $(3.06 \mathrm{mg} / 100 \mathrm{~g})$ in comparison with those without the inclusion of vitamin
E $(2.42 \mathrm{mg} / 100 \mathrm{~g})$, and there were no differences in the other variables studied. Falandysz et al. (1991) analyzed the concentration of iron in the kidneys of lambs and found a value similar to the reported in this research $(3.7 \mathrm{mg} / 100 \mathrm{~g})$. For the centesimal composition of kidneys, the average values of the treatments were of $1.2 \mathrm{~g}$ of dry matter $/ 100 \mathrm{~g}$, $13.8 \mathrm{~g}$ of crude protein/100 g, $2.6 \mathrm{~g}$ of ether extract/100 $\mathrm{g}$ and $81.7 \mathrm{~g}$ of moisture $/ 100 \mathrm{~g}$.

No difference was observed $(\mathrm{P}>0.05)$ in the chemical composition of the meat of lambs fed sugarcane associated with sunflower seeds and vitamin E (Table 5). The sunflower seed increases the content of ether extract of the diet; however, it does not increase the content of lipids in the muscle of lambs.

Falandysz et al. (1991) evaluated the concentration of minerals in the meat of lambs fed native pasture and reported values of $2.0 \mathrm{mg}$ of iron/100 g and $3.4 \mathrm{mg}$ of zinc/ $100 \mathrm{~g}$, higher than the values of this study, and $0.01 \mathrm{mg}$ of manganese $/ 100 \mathrm{~g}$ and $0.09 \mathrm{mg}$ of copper/100 $\mathrm{g}$, which are lower than the values of this study (Table 5). Other researchers who used ingredients other than sunflower seeds and vitamin E obtained similar values, like Carvalho \& Brochier (2008), who evaluated the chemical composition of the meat of lambs in feedlot finishing fed diets containing increasing levels of brewery residue, reporting average values of 1.10 ; 19.26; 1.09 ; and $75.28 \mathrm{~g} / 100 \mathrm{~g}$ of mineral matter, crude protein, ether extract and moisture, respectively, which can indicate the non-influence of the type of diet ingested by the lambs in the qualitative characteristics of the meat.

The composition of the meat from sheep of different categories has average values of $75 \mathrm{~g}$ of moisture/100 g, $19 \mathrm{~g}$ of protein/100 g, $4 \mathrm{~g}$ of ether extract/100 $\mathrm{g}$ and $1 \mathrm{~g}$ of mineral matter/100 g (Prata, 1999). These values can oscillate due to the finishing degree of the animal, resulting

Table 4 - Centesimal and mineral compositions in the liver of lambs fed sugar cane associated with sunflower seeds and vitamin E

\begin{tabular}{|c|c|c|c|c|c|c|c|c|c|}
\hline \multirow{2}{*}{ Variable } & \multicolumn{2}{|c|}{ Sunflower seed $(\mathrm{S})$} & \multicolumn{2}{|c|}{ Vitamin E (E) } & \multirow{2}{*}{ Mean } & \multicolumn{2}{|c|}{ Probability } & \multicolumn{2}{|c|}{ Interaction $(\mathrm{S} \times \mathrm{E})$} \\
\hline & With & Without & With & Without & & $\mathrm{S}$ & $\mathrm{E}$ & CV $(\%)$ & $\mathrm{F}$ \\
\hline \multicolumn{10}{|l|}{$\mathrm{g} / 100 \mathrm{~g}$} \\
\hline Mineral matter & 2.12 & 1.87 & 1.88 & 2.11 & 2.01 & 0.61 & 0.65 & 38.98 & 0.73 \\
\hline Crude protein & 19.71 & 20.35 & 20.25 & 19.82 & 20.01 & 0.10 & 0.24 & 2.77 & 0.38 \\
\hline Ether extract & 2.45 & 2.62 & 2.34 & 2.42 & 2.36 & 0.21 & 0.57 & 9.64 & 0.67 \\
\hline $\begin{array}{l}\text { Moisture } \\
\mathrm{mg} / 100 \mathrm{~g}\end{array}$ & 74.86 & 74.35 & 74.99 & 75.21 & 74.85 & 0.37 & 0.77 & 5.44 & 0.11 \\
\hline Sodium & 58.77 & 60.72 & 58.79 & 60.70 & 59.93 & 0.75 & 0.76 & 16.40 & 0.22 \\
\hline Potassium & 229.15 & 239.16 & 237.62 & 230.69 & 234.34 & 0.43 & 0.58 & 8.40 & 0.57 \\
\hline Magnesium & 17.38 & 19.13 & 18.14 & 18.37 & 18.21 & 0.15 & 0.83 & 9.73 & 0.39 \\
\hline Calcium & 8.59 & 6.95 & 6.18 & 9.36 & 7.61 & 0.37 & 0.11 & 37.29 & 0.30 \\
\hline Iron & $3.91 \mathrm{a}$ & $2.58 \mathrm{~b}$ & $4.68 \mathrm{a}$ & $1.80 \mathrm{~b}$ & 3.44 & $<0.01$ & $<0.01$ & 17.30 & 0.48 \\
\hline Manganese & 0.25 & 0.28 & 0.29 & 0.24 & 0.27 & 0.29 & 0.13 & 16.58 & 0.20 \\
\hline Zinc & 2.66 & 2.81 & 2.60 & 2.86 & 2.70 & 0.56 & 0.32 & 15.14 & 0.29 \\
\hline Copper & 4.35 & 4.92 & 4.43 & 4.83 & 4.61 & 0.42 & 0.57 & 23.97 & 0.43 \\
\hline
\end{tabular}

Means followed by different letters differ $(\mathrm{P}<0.05)$ by the Tukey test. $\mathrm{CV}$ - coefficient of variation; F - probability. 
Table 5 - Chemical and mineral compositions in the meat of lambs fed sugarcane associated with sunflower seeds and vitamin E

\begin{tabular}{|c|c|c|c|c|c|c|c|c|c|}
\hline \multirow{2}{*}{ Variable } & \multicolumn{2}{|c|}{ Sunflower seed (S) } & \multicolumn{2}{|c|}{ Vitamin E (E) } & \multirow{2}{*}{ Mean } & \multicolumn{2}{|c|}{ Probability } & \multicolumn{2}{|c|}{ Interaction $(\mathrm{S} \times \mathrm{E})$} \\
\hline & With & Without & With & Without & & $\mathrm{S}$ & E & CV $(\%)$ & $\mathrm{F}$ \\
\hline \multicolumn{10}{|l|}{$\mathrm{g} / 100 \mathrm{~g}$} \\
\hline Mineral matter & 1.01 & 1.04 & 1.00 & 1.05 & 1.02 & 0.39 & 0.33 & 6.32 & 0.36 \\
\hline Crude protein & 18.09 & 18.58 & 18.14 & 18.53 & 18.28 & 0.30 & 0.41 & 3.97 & 0.57 \\
\hline Ether extract & 1.85 & 1.64 & 1.52 & 1.97 & 1.73 & 0.67 & 0.37 & 45.15 & 0.92 \\
\hline $\begin{array}{l}\text { Moisture } \\
\mathrm{mg} / 100 \mathrm{~g}\end{array}$ & 78.96 & 78.34 & 79.26 & 78.04 & 78.65 & 0.21 & 0.05 & 2.94 & 0.37 \\
\hline Sodium & 44.29 & 41.94 & 46.76 & 39.46 & 43.31 & 0.60 & 0.13 & 16.25 & 0.26 \\
\hline Potassium & 290.96 & 279.86 & 285.68 & 285.14 & 284.88 & 0.39 & 0.96 & 6.99 & 0.09 \\
\hline Magnesium & 19.24 & 19.20 & 19.53 & 18.91 & 19.18 & 0.97 & 0.59 & 9.54 & 0.20 \\
\hline Calcium & 7.05 & 8.58 & 8.36 & 7.27 & 7.76 & 0.16 & 0.30 & 20.77 & 0.44 \\
\hline Iron & 0.88 & 0.93 & 0.89 & 0.93 & 0.89 & 0.62 & 0.64 & 18.23 & 0.16 \\
\hline Manganese & 0.05 & 0.04 & 0.05 & 0.04 & 0.04 & 0.57 & 0.18 & 24.53 & 0.88 \\
\hline Zinc & 1.47 & 1.55 & 1.57 & 1.45 & 1.51 & 0.67 & 0.52 & 19.13 & 0.61 \\
\hline Copper & 0.46 & 0.31 & 0.52 & 0.24 & 0.40 & 0.27 & 0.05 & 50.92 & 0.68 \\
\hline
\end{tabular}

$\mathrm{P}>0.05$ by the Tukey test.

$\mathrm{CV}$ - coefficient of variation; F - probability.

in a variation in the protein, fat and water; the last one is the most important, quantitatively, and the lean red meat can contain more than $76 \mathrm{~g}$ of water/100 g (Sañudo et al., 2008), as verified in this study.

The composition of vitamin $\mathrm{E}$ differed $(\mathrm{P}<0.05)$ in the non-carcass components and in the meat of the lambs fed diets with the inclusion of sunflower seeds and vitamin $\mathrm{E}$ in the concentrate (Table 6). The content of vitamin $\mathrm{E}$ in the heart of the animals fed the control diet was higher than those fed vitamin E or vitamin E + sunflower seeds. Numerically, the heart of the lambs from the control treatment presented a higher content of fat, which is the place with the major storage of vitamin E (McDowell, 2000), although the ether extract of this organ did not differ $(\mathrm{P}>0.05)$ between the treatments.

Lopez-Bote et al. (2001) evaluated the influence of vitamin E levels in the diet on the performance and the quality of lamb meat and found values of vitamin $E$ in the muscle $(0.70 \mathrm{mg} / 100 \mathrm{~g})$, with the inclusion of $1020 \mathrm{mg}$ of vitamin $\mathrm{E} / \mathrm{kg}$ of DM analogous to this study, which included $1000 \mathrm{mg}$ of vitamin E/ $\mathrm{kg}$ of DM. The values of vitamin E in the sheep meat cited by Strohecker et al. (1997) are in accordance with the ones of this research, of $0.42 \mathrm{mg} / 100 \mathrm{~g}$ of vitamin $\mathrm{E}$ in the muscle of lambs.

Guidera et al. (1997) reported values of 0.98; 2.06; 0.77 ; 0.55 ; and $0.53 \mathrm{mg} / 100 \mathrm{~g}$ of vitamin $\mathrm{E}$ in the heart, liver, lungs, kidneys and muscle, respectively, for lambs supplemented with $1000 \mathrm{mg} / \mathrm{kg}$ of DM of the diet, similar to the results of this research, except for the liver and the kidneys: $1.08 ; 0.89 ; 0.71 ; 0.94$; and $0.63 \mathrm{mg} / 100 \mathrm{~g}$ of vitamin $\mathrm{E}$ for the same organs, respectively. The amount of vitamin $E$ in the liver of lambs of this study $(0.89 \mathrm{mg} / 100 \mathrm{~g})$ was lower than the cited by Guidera et al. (1997), of
Table 6 - Composition in vitamin E (mg/100 g) in the non-carcass components and in the meat of lambs fed sugarcane associated with sunflower seeds and vitamin E

\begin{tabular}{|c|c|c|c|c|c|}
\hline \multirow{2}{*}{$\begin{array}{l}\text { Non-carcass } \\
\text { component }\end{array}$} & \multicolumn{3}{|c|}{ Treatment } & \multirow{2}{*}{$\mathrm{F}$} & \multirow{2}{*}{ CV $(\%)$} \\
\hline & $\mathrm{C}$ & $\mathrm{V}$ & SV & & \\
\hline Heart & $1.21 \mathrm{a}$ & $1.08 \mathrm{~b}$ & $0.86 \mathrm{c}$ & $<0.01$ & 5.14 \\
\hline Liver & $0.42 \mathrm{c}$ & $0.89 a$ & $0.71 b$ & $<0.01$ & 3.77 \\
\hline Tongue & $0.64 \mathrm{c}$ & $0.95 \mathrm{a}$ & $0.75 b$ & $<0.01$ & 2.91 \\
\hline Lungs & $0.91 \mathrm{a}$ & $0.71 b$ & $0.54 \mathrm{c}$ & $<0.01$ & 7.07 \\
\hline Reticulum & $0.61 \mathrm{a}$ & $0.41 b$ & $0.41 b$ & $<0.01$ & 7.64 \\
\hline Kidneys & $0.91 \mathrm{a}$ & $0.94 \mathrm{a}$ & $0.66 \mathrm{~b}$ & $<0.01$ & 6.73 \\
\hline Meat & $0.35 \mathrm{c}$ & $0.63 b$ & $0.77 \mathrm{a}$ & $<0.01$ & 5.73 \\
\hline
\end{tabular}

Means followed by different letters differ $(\mathrm{P}<0.05)$ by the Tukey test.

$\mathrm{CV}$ - coefficient of variation; $\mathrm{F}$ - probability; $\mathrm{C}$ - control treatment; $\mathrm{V}$ - inclusion of vitamin $\mathrm{E} ; \mathrm{SV}$ - inclusion of sunflower seeds and vitamin $\mathrm{E}$.

$2.06 \mathrm{mg} / 100 \mathrm{~g}$. This was probably due to the higher amount of iron, which is a mineral with a high oxidative capacity (Underwood et al., 1999) in the liver of lambs fed sunflower seeds and vitamin E, oxidizing the vitamin $\mathrm{E}$ and reducing its storage in this organ.

In the comparison of the qualitative (nutritional) characteristics of the non-carcass components among themselves and the meat, aiming at technical backing to the appreciation of these components which are usually neglected, differences are observed $(\mathrm{P}<0.05)$ in all the variables, except for moisture (Table 7).

A higher content of mineral matter was observed in the liver $(2.01 \mathrm{~g} / 100 \mathrm{~g})$, approximately 48\% higher than the value observed in the meat, being the edible organ most commonly used in cooking and as an ingredient in reformed foods (Forrest et al., 1975). Along with the heart, it has greater acceptance by consumers in relation to the other non-carcass components.

The crude protein of the liver was higher $(\mathrm{P}<0.05)$ than that of the meat, with values of 20.01 and $18.34 \mathrm{~g} / 100 \mathrm{~g}$, 
respectively; the reticulum is the organ with the lowest content of protein $(10.85 \mathrm{~g} / 100 \mathrm{~g})$. A possible explanation is because the liver has numerous blood vessels and metabolizes several nutrients, hence its superior nutritional value, unlike the reticulum (Table 7).

The highest values of ether extract were observed in the heart and in the tongue: 9.57 and $5.74 \mathrm{~g} / 100 \mathrm{~g}$, respectively. Anderson (1988) also reported elevated levels of ether extract in the heart and in the tongue of sheep (5.69 and $17.51 \mathrm{~g} / 100 \mathrm{~g}$, respectively).

The heart was the non-carcass component with the highest level of vitamin E $(1.03 \mathrm{mg} / 100 \mathrm{~g})$, value $40 \%$ superior to that of the meat. Even knowing that the vitamin $\mathrm{E}$ is stored in the liver, the fat tissue stores an almost unlimited quantity of vitamin $\mathrm{E}$ and all the tissues present detectable quantities of this vitamin (McDowell, 2000).

It is possible to observe that the non-carcass components with the highest values of fat consequently presented higher levels of vitamin E, and even with the fact that the liver is the location of its storage, it is found with a higher expression in the organs with higher contents of fat (heart and tongue) and also in the kidney, the organ responsible for the blood filtering. In the lungs, high concentrations of vitamin E can be attributed to the abundant supply of blood to this organ (Hidiroglou et al., 1990).

There are great variations in the concentrations of vitamin $\mathrm{E}$ in the literature, which can be attributed to the levels of vitamin $\mathrm{E}$ in the diets, to the analytical procedures (Lopez-Bote et al., 2001), to the management of the animals and to the usage time.

Hidiroglou et al. (1990) evaluated the plasmatic and tissue concentrations of vitamin $\mathrm{E}$ of sheep after an intraperitoneal injection of a single dose of vitamin $\mathrm{E}$ and found results fairly similar to those of this research, and the different contents of vitamin $\mathrm{E}$ were due to the experimental methodology. The liver and the lungs of the sheep presented similar contents of vitamin $\mathrm{E}$ in the abovementioned study ( 27.0 and $21.6 \mathrm{mg} / 100 \mathrm{~g}$, respectively), as well as the kidneys and the heart ( 3.3 and $2.7 \mathrm{mg} / 100 \mathrm{~g}$, respectively). However, in this research, what possibly caused the higher content of vitamin $\mathrm{E}$ in the heart $(1.03 \mathrm{mg} / 100 \mathrm{~g})$ in comparison with the liver and lungs $(0.70$ and $0.71 \mathrm{mg} / 100 \mathrm{~g}$, respectively) was the fact that the sheep were continuously fed a diet rich in vitamin $\mathrm{E}$, with the possibility of its storage in the fat tissue. When administered in a single dose, in a few days before slaughter (as in the research above), vitamin E can enable the liver to store the excess of vitamin E (Hidiroglou et al., 1990), once this is the organ with the highest metabolic rate.

According to Hathcock (1997), the daily ingestion of at least $67 \mathrm{mg}$ of vitamin $\mathrm{E}$ is related to the reduction of cardiovascular diseases. The levels of vitamin $\mathrm{E}$ in the heart, kidneys and tongue were 41,26 and $24 \%$, respectively, superior to the meat.

The lungs and the kidneys were the organs with the highest contents of sodium $(\mathrm{P}<0.05), 138.4$ and $137.5 \mathrm{mg} /$ $100 \mathrm{~g}$, respectively (Table 8), and the results agree with the 157 and $157 \mathrm{mg}$ of sodium/100 $\mathrm{g}$ of lungs and kidneys of sheep reported by Anderson (1988). The lungs and the kidneys are organs essential to life, and a priority in the use of nutrients, as described by Ferreira et al. (2000); this explains the high content of minerals, like sodium, constant in these organs.

The highest content of potassium was observed in the meat $(285.73 \mathrm{mg} / 100 \mathrm{~g})$, and it agrees with McDowell (1992), who describes that two-thirds of all the potassium present in the body (approximately $0.3 \%$ of the body dry matter) are located in the skin and in the meat. The liver presented $82 \%$ of the potassium, and it is the place that stores glycogen, needing the presence of potassium (Martin, 1993). The intake of a portion of $100 \mathrm{~g}$ of liver supplies around $12 \%$ of the nutritional requirement of potassium for a male adult, which is analoguous to the meat, which supplies 14\% (NRC, 1989).

The kidneys contain $58 \%$ more calcium than the meat and the lungs $61 \%$, being the organs with the highest contents of this mineral $(\mathrm{P}<0.05)$. The excretion of calcium in the urine is minimal, due to the efficiency of its reabsorption in

Table 7 - Chemical and vitamin E compositions of the non-carcass components and the meat of lambs

\begin{tabular}{|c|c|c|c|c|c|c|c|c|c|}
\hline \multirow{2}{*}{ Variable } & \multicolumn{6}{|c|}{ Non-carcass components } & \multirow{2}{*}{ Meat } & \multirow{2}{*}{ Probability } & \multirow{2}{*}{ CV $(\%)$} \\
\hline & Heart & Liver & Tongue & Lungs & Reticulum & Kidneys & & & \\
\hline \multicolumn{10}{|l|}{$\mathrm{g} / 100 \mathrm{~g}$} \\
\hline Mineral matter & $1.25 \mathrm{~b}$ & $2.01 \mathrm{a}$ & $1.08 \mathrm{bc}$ & $0.98 \mathrm{c}$ & $0.58 \mathrm{~d}$ & $1.24 \mathrm{~b}$ & $1.03 \mathrm{bc}$ & $<0.01$ & 27.12 \\
\hline Crude protein & $14.85 \mathrm{c}$ & $20.01 \mathrm{a}$ & $15.27 \mathrm{c}$ & $15.25 \mathrm{c}$ & $10.85 \mathrm{~d}$ & $13.84 \mathrm{c}$ & $18.34 \mathrm{~b}$ & $<0.01$ & 5.19 \\
\hline Ether extract & $9.57 \mathrm{a}$ & $2.36 \mathrm{~cd}$ & $5.74 b$ & $1.10 \mathrm{~d}$ & $3.63 \mathrm{c}$ & $2.70 \mathrm{~cd}$ & $1.71 d$ & $<0.01$ & 55.87 \\
\hline $\begin{array}{l}\text { Moisture } \\
\mathrm{mg} / 100 \mathrm{~g}\end{array}$ & 73.48 & 74.85 & 77.51 & 81.97 & 84.58 & 81.70 & 78.65 & 0.13 & 4.89 \\
\hline Vitamin E & $1.03 \mathrm{a}$ & $0.70 \mathrm{~b}$ & $0.80 \mathrm{ab}$ & $0.71 b$ & $0.45 \mathrm{c}$ & $0.82 \mathrm{ab}$ & $0.61 b c$ & $<0.01$ & 21.66 \\
\hline
\end{tabular}

Means followed by different letters differ $(\mathrm{P}<0.05)$ by Tukey test.

$\mathrm{CV}$ - coefficient of variation. 
Table 8 - Composition $(\mathrm{mg} / 100 \mathrm{~g})$ of macro and trace minerals of the non-carcass components and meat of lambs

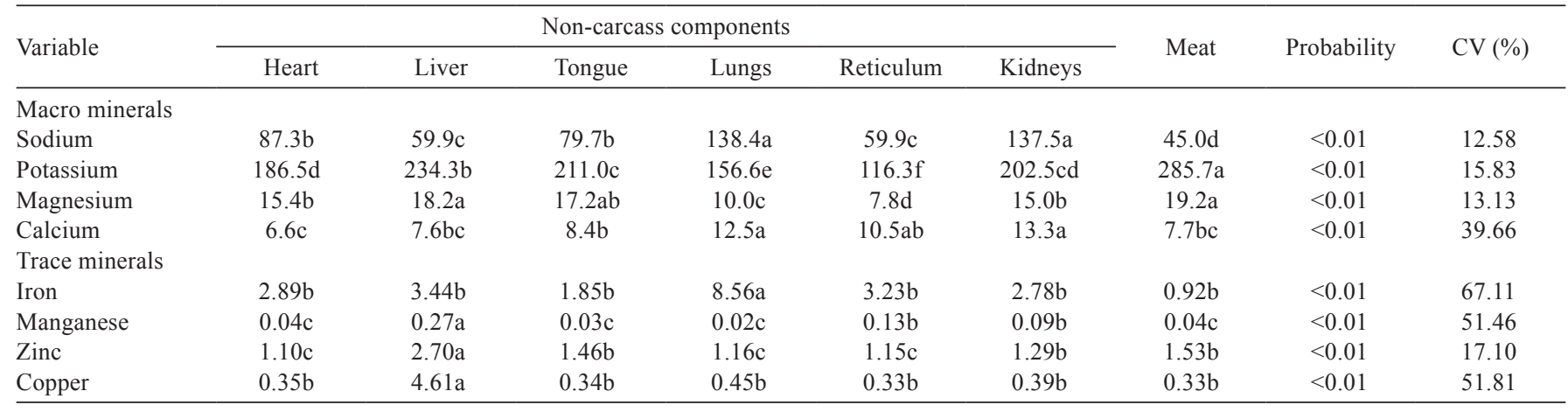

Means followed by different letters differ $(\mathrm{P}<0.05)$ by the Tukey test. $\mathrm{CV}$ - coefficient of variation.

the kidneys, which explains the high levels in this organ. In the lungs, the abundant supply of blood (Hidiroglou et al., 1990), which is rich in nutrients, leads to high nutritional values of this organ, and the calcium is present in elevated concentrations in the plasma (Martin, 1993).

The magnesium is involved in the metabolism of carbohydrates and lipids as a catalyzer of a great variety of enzymes, and it is important for functions like muscle contraction and it is present in the proteins and in the fats (Martin, 1993). The highest contents of magnesium were observed in the meat $(19.2 \mathrm{mg} / 100 \mathrm{~g})$, in comparison with the other non-carcass components, except for the liver and the tongue (18.2 and $17.2 \mathrm{mg} / 100 \mathrm{~g}$, respectively); liver has $94 \%$ of the total observed in the meat. Anderson (1988) observed values of $24 \mathrm{mg} / 100 \mathrm{~g}$ in the meat, $17 \mathrm{mg} / 100 \mathrm{~g}$ in the liver and $22 \mathrm{mg} / 100 \mathrm{~g}$ in the tongue, corroborating the results of this study.

The values of iron in the non-carcass components and in the meat were lower than the reported by Anderson (1988), except for the lungs $(8.56 \mathrm{mg} / 100 \mathrm{~g})$ (Table 8$)$, possibly due to the large blood supply of this organ, as explained by Hidiroglou et al. (1990). According to the contents of iron of this research, the ingestion of $100 \mathrm{~g}$ of lung would supply $80 \%$ of the requirement of this mineral in male adults, while the same proportion of meat would supply around $10 \%$ (NRC, 1989).

Bellof et al. (2006) studied the concentration of copper, iron, manganese and zinc in the muscle of the Merino breed slaughtered with different body weights and diets, and reported copper and manganese contents in the muscle of $0.08 \mathrm{mg} / 100 \mathrm{~g}$ and $0.02 \mathrm{mg} / 100 \mathrm{~g}$, respectively. The copper value is lower than the observed in this research $(0.33 \mathrm{mg} / 100 \mathrm{~g})$, while the zinc $(3.42 \mathrm{mg} / 100 \mathrm{~g})$ and iron contents $(1.31 \mathrm{mg} / 100 \mathrm{~g})$ were higher than the results obtained herein(1.53 and $0.92 \mathrm{mg} / 100 \mathrm{~g}$, respectively).
The highest contents of copper and manganese are found in the liver $(\mathrm{P}<0.05)$ in comparison with the other non-carcass components and the meat. The copper is fundamental to metabolism, and it is stored in the liver (Cavalheiro \& Trindade, 1992; McDowell, 1992). The manganese is indispensable to the rumen microorganisms and is also stocked in the liver (Cavalheiro \& Trindade, 1992).

According to Silva Sobrinho (2008) the meat stands out by the presence of minerals like potassium, sodium, magnesium, iron and zinc, essential to the human organism. Comparing the trace minerals and macro minerals of the non-carcass components and those of the meat, equivalent or high values are observed, like the liver, lungs and the kidneys, which highlights the quality of these organs and the possibility of using them in the preparation of dishes, using one or more organs, and also in processed and reformed products such as hamburgers and sausages, widely used in other countries (Anderson, 1988), decreasing the waste of nutrients and increasing the economic value.

\section{Conclusions}

The inclusion of sunflower seeds and vitamin $\mathrm{E}$ in diets modifies the nutritional composition of iron and vitamin $\mathrm{E}$ of the non-carcass components and of the meat of Ile de France lambs. Diets with the inclusion of sunflower seeds and vitamin E promote high contents of vitamin E for the non-carcass components and meat, bringing quality to these products. Although the liver stood out by its qualitative characteristics in comparison with the other non-carcass components and the meat, overall, the noncarcass components are nutritionally equivalent to the sheep meat. 


\section{References}

ANDERSON, B.A.E. Composition and nutritional value of edible meat by-products. In: PEARSON, A.M.; DUTSON, T.R. (Eds.) Edible meat by-products. London: Elsevier, 1988. Cap.1, p. 15-45.

BELLOF, G.; MOST, E.; PALLAUF, J. Concentration of Ca, P, Mg, $\mathrm{Na}$ and $\mathrm{K}$ in muscle, fat and bone tissue of lambs of the breed German Merino Land sheep in the course of the growing period. Journal of Animal Physiology and Animal Nutrition, v.90, p.385-393, 2006.

BRIGELIUS, F.R.; KELLY, F.J.; SALONEN, J.T. et al. The European perspective on vitamin E: current knowledge and future research. American Journal of Clinical Nutrition, v.76, p.703-716, 2002.

BRUBACHER, G.; MULLER-MULOT, W.; SOUTHGATE, D.A.T. Methods for the determination of vitamins in food recommended by COST 91. New York: Elsevier, 1985. p.97-106.

CARVALHO, S.; BROCHIER, M.A. Composição tecidual e centesimal e teor de colesterol da carne de cordeiros terminados em confinamento com dietas contendo níveis crescentes de resíduo úmido de cervejaria. Ciência Rural, v.38, p.2023-2028, 2008.

CAVALHEIRO, A.C.L.; TRINDADE, D.S. Os minerais para bovinos e ovinos criados em pastejo. Porto Alegre: Sagra - DC Luzzato, 1992. 142p.

CEZAR, M.F.; SOUSA, W.H. Carcaças ovinas e caprinas: Obtenção, avaliação, classificação. Uberaba: Agropecuária Tropical, 2007. $232 \mathrm{p}$.

COLE, N.A. Influence of a three-day feed and water deprivation period on gut fill, tissue weights and tissue composition in mature weathers. Journal of Animal Science, v.73, p.2548-2557, 1995.

COSTA, R.G.; SANTOS, N.M.; MEDEIROS, A.N. et al. Buchada caprina: características físico-químicas, e microbiológicas. Areia: UFPB/CCA, 2007. 93p.

CUNNIFF, P.A. Official methods of analyses of AOAC international. 16.ed. Arlington: Association of Official Analysis Chemistry, 1998. v.2.

DAVOGLIO, S.; MOTA, A.F.F.; SANTELlO, G.A. et al. Peso e rendimentos dos componentes extra-carcaça de cordeiros $1 / 2$ Dorper Santa Inês. In: ENCONTRO ANUAL DE INICIAÇÃO CIENTÍFICA, 16., 2007, Maringá. Anais... Maringá: EAIC, 2007 (CD-ROM).

DEFELIPO, B.V.; RIBEIRO, A.C. Análises químicas do solo: metodologias. Viçosa, MG: UFV, 1981. 17p.

FALANDYSZ, J. Manganese, copper, zinc, iron, cadmium, mercury and lead in muscle meat, liver and kidney of poultry, rabbit and sheep slaughtered in the northern part of Poland. Food Additives \& Contaminants, v.8, p.71-83, 1991.

FERNANDES, A.R.M.; SAMPAIO, A.A.M.; HENRIQUE, W. et al. Características da carcaça e da carne de bovinos sob diferentes dietas em confinamento. Arquivo Brasileiro de Medicina Veterinária e Zootecnia, v.60, p.139-147, 2008.

FERREIRA, M.A.; VALADARES FILHO, S.C.; MUNIZ, E.B. et al. Características das carcaças, biometria do trato gastrintestinal, tamanho dos órgãos internos e conteúdo gastrintestinal de bovinos F1 Simental x Nelore, alimentados com vários níveis de concentrados. Revista Brasileira de Zootecnia, v.29, p.1174-1182, 2000.

FERRELL, C.L.; GARRETT, W.N.; HINMAN, N. Estimation of body composition in pregnant and non-pregnant heifers. Journal Animal Science, v.42, p.1158-1166, 1976.

FORREST, J.C.; ABERLE, E.D.; HEDRICK, H.B. et al. Principles of meat science, San Francisco, 1975. p.288.

GARCIA, C.A. Avaliação de resíduo de panificação "biscoito" na alimentação de ovinos e nas características quantitativa e qualitativa das carcaças. 1998. 79f. Dissertação (Mestrado em Zootecnia) - Faculdade de Ciências Agrárias e Veterinárias, Universidade Estadual Paulista, Jaboticabal.
GUIDERA, J.; KERRY, J.P.; BUCKLEY, D.J. et al. The effect of dietary vitamin $\mathrm{E}$ supplementation on the quality of fresh and frozen lamb meat. Meat Science, v.45, p.33-43, 1997.

HATHCOCK, J.N. Vitamins and minerals: efficacy and safety. American Journal of Clinical Nutrition, v.66, p.427-37, 1997.

HIDIROGLOU, M. Vitamin E response in sheep to various modes of administration. International Journal of Vitamin and Nutrition Research, v.56, p.247-252, 1986.

HIDIROGLOU, N.; BUTLER, G.; MCDOWELL, L. R. Plasma and tissue vitamin E concentrations in sheep after administration of a single intraperitoneal dose of dl- $\alpha$-tocopherol. Journal of Animal Science, v.68, p.782-787, 1990.

HOMEM JUNIOR, A.C. Grãos de girassol ou gordura protegida na dieta com alto concentrado e o ganho compensatório para cordeiros confinados. 2008. 79f. Dissertação (Mestrado em Zootecnia) - Universidade Estadual Paulista "Julio de Mesquita Filho"/Faculdade de Ciências Agrárias e Veterinárias, Jaboticabal.

LOPEZ-BOTE, C.J.; DAZA, A.; SOARES, M. et al. Dose-response effect of dietary vitamin $\mathrm{E}$ concentration on meat quality characteristics in light-weight lambs. Animal Science, v.73, p.451-457, 2001.

MALAVOLTA, E.; VITTI, G.C.; OLIVEIRA, S.A. Avaliação do estado nutricional das plantas: Princípios e aplicações. Piracicaba: Potafos, 1989. 201p.

MARTIN; TAYAROL, L.C. Nutrição mineral de bovinos de corte. São Paulo: Nobel, 1993, 173p.

McDOWELL, L.R. Minerals in animal and human nutrition. San Diego: Academic Press, 1992. 524p.

McDOWELL, L.R. Vitamins in animal and human nutrition. Iowa: Iowa State University Press, 2000. 793p.

MOLENTO, M.B.; TASCA, C.; GALLO, A. et al. Método Famacha como parâmetro clínico individual de infecção por Haemonchus contortus em pequenos ruminantes. Ciência Rural, v.34, p.1139-1145, 2004.

MONTEIRO JÚNIOR, L.A. Avaliação das técnicas de insensibilização de ovinos abatidos na região de Botucatu. 2000. 166f. Dissertação (Mestrado em Medicina Veterinária) - Faculdade de Medicina Veterinária e Zootecnia, Universidade Estadual Paulista, Botucatu.

NATIONAL RESEARCH COUNCIL - NRC. Nutrient requirements of small ruminants: sheep, goats, cervids and new camelids. 1.ed. Washington: National Academic Press, 2006. 362p.

NATIONAL RESEARCH COUNCIL - NRC. Recommended dietary allowances (RDA). 10.ed. Washington, D.C.: National Academy Press, 1989. 284p.

PRATA, L.F. Higiene e inspeção de carnes, pescado e derivados. Jaboticabal: FUNEP, 1999. 217p.

PURCHAS, R.W.; SILVA SOBRINHO, A.G.; GARRICK, D.J. et al. Effects of age at slaughter and sire genotype on fatness, muscularity, and the quality of meat from ram lambs born to Romney ewes. New Zealand Journal of Agricultural Research, v.45, p.77-86, 2002

SAÑUDO, C.; ARRIBAS, M.D.M.C.; SILVA SOBRINHO, A.G. Qualidade da carcaça e da carne ovina e seus fatores determinantes. In: SILVA SOBRINHO, A.G.; SAÑUDO, C.; OSÓRIO, J.C.S. et al. (Eds.) Produção de carne ovina. Jaboticabal: Funep, 2008. p.177-228.

SHAPIRO, J.A.; KOEPSELL, T.D.; VOIGT, L.F. et al. Diet and rheumatoid arthritis in women: a possible protective effect of fish consumption. Epidemiology, v.7, p.256-263, 1996.

SILVA SOBRINHO, A.G.; OSÓRIO, J.C.S. Aspectos quantitativos da produção de carne ovina. In: SILVA SOBRINHO, A.G.; SAÑUDO, C.; OSÓRIO, J.C.S. et al. (Eds.) Produção de carne ovina. Jaboticabal: FUNEP, 2008. p.1-68.

SILVA, D.J.; QUEIROZ, A.C. Análise de alimentos: métodos químicos e biológicos. 3.ed. Viçosa, MG: UFV, 2006. 235p. 
SLOSS, M.W.; ZAJAC, A.M.; KEMP, R.L. Parasitologia clínica veterinária. São Paulo: Manole, 1999. 198p.

STROHECKER, M.G.; FAUSTMAN, C.; FURR, H. et al. Vitamin E supplementation effects on color and lipid stability of whole and ground lamb. Journal of Muscle Foods, v.8, p.413-426, 1997.
UNDERWOOD, E.J.; F.SUTTLE. The mineral nutrition of Livestock. 3.ed. Wallingford: CABI Publishing, 1999. 614p.

YAMAMOTO, S.M.; MACEDO, F.A.F.; MEXIA, A.A. et al. Rendimento dos cortes e não-componentes das carcaças de cordeiros terminados com dietas contendo diferentes fontes de óleo vegetal. Ciência Rural, v.34, p.1909-1913, 2004. 